Ljiljana Rajnović ${ }^{1}$

Jonel Subić ${ }^{2}$

Institute of Agricultural Economics, Belgrade
SCIENTIFIC REVIEW ARTICLE

DOI: 10.5937/ekonomika2104091R

Received: Jun, 16. 2021.

Accepted: October, 14. 2021.

\title{
CORPORATE BONDS AS A WAY OF FINANCING COMPANIES IN THE REPUBLIC OF SERBIA ${ }^{3}$
}

\begin{abstract}
The security of sources of financing is of undoubted importance for the continuous and sustainable operation of economic entities, which is a long-term interest of persons interested in the operation of economic entities. In the structure of possible sources of financing of economic entities, corporate bonds are of great importance everywhere in the world, and their application in the Republic of Serbia could bring a great contribution to the domestic economy. Corporate bonds are debt obligations issued by corporation to debt refinansing, improvements, expansions or acquisitions. The bondholders are the issuer's creditors and for the money invested in the company, they expect earnings. The main goal of this paper is to consider the conditions and importance of issuing corporate bonds by medium and large companies in Serbia and the advantage over other sources of financing. Based on the obtained research results, it can be concluded that the issuance of bonds is a good alternative to other sources of financing the company's operations, but the corporate bond market in Serbia is in the development phase. Bond issuers with listing on the regulated market of the Belgrade Stock Exchange include, in addition to the state, only certain commercial banks and international financial organizations.
\end{abstract}

Keywords: Bonds, securities, corporate bonds, securities market, issuer financing.

Jel classification: $Q 14$

\section{KORPORATIVNE OBVEZNICE KAO NAČIN FINANSIRANJA PRIVREDNIH DRUŠTAVA U REPUBLICI SRBIJI}

\begin{abstract}
Apstrakt
Sigurnost izvora finansiranja ima nesumnjiv značaj za kontinuirano $i$ održivo poslovanje privrednih subjekata, što predstavlja dugoročni interes lica zainteresovanih za poslovanje privrednih subjekata. U strukturi mogućih izvora finansiranja privrednih subjekata, korporativne obveznice imaju veliki značaj svuda u svetu, a njihova primena u Republici Srbiji mogla bi doneti veliki doprinos

\footnotetext{
${ }^{1}$ rajnoviclj@gmail.com, Orcid id 0000-0002-8209-9088

2 jonel_s@iep.bg.rs, Orcid id 0000-0003-1342-1325

${ }^{3}$ Paper is a part of research, financed by the Ministry of Education, Science and Technological Development of the Republic of Serbia.
} 
domaćoj privredi. Corporate bonds are debt obligations issued by corporation to debt refinansing, improvements, expansions or acquisitions. Imaoci obveznica su poverioci izdavaoca i za uloženi novac u kompaniju, očekuju zaradu. Osnovni cilj ovog rada je da razmotri uslove i značaj emitovanja korporativnih obveznica od strane srednjih $i$ velikih preduzeća u Srbiji i prednost u odnosu na druge izvore finansiranja. Na osnovu dobijenih rezultatima istraživanja, može se zaključiti da izdavanje obveznica predstavlja dobru alternativu drugim izvorima finanisranja poslovanja preduzeća, ali je tržište korporativnih obveznica u Srbiji u fazi razvoja. Izdavaoci obveznica sa listingom na regulisanom tržištu Beogradske berze uključuju osim države, samo pojedine poslovne banke i međunarodne finansijske organizacije.

Ključne reči: Obveznice, hartije od vrednosti, korporativne obveznice, tržište hartija od vrednosti, finansiranje izdavaoca.

\section{Intraduction}

Every company during its financial activity must provide itself with the necessary sources of financing. Also, in the course of business, companies, regardless of profile, plan their development and growth, through the implementation of certain investment projects. However, what will be achieved from what is planned will depend, above all, on the available and available to the issuer, primarily external, financial resources (Rajnović, Subić, Zakić, 2016), in the growth phase or the need to downsize the company. Generally speaking, the provision of additional funds can be based on two forms of financing - financing with own or other people's (borrowed) funds, or partly with own and partly borrowed funds, which in practice is the most common case (Rajnović, Subić, Zakić, 2016).

In this paper, the authors want to show the advantages of financing companies by issuing bonds:

- by opting for external financing, the company can obtain additional funds by issuing bonds, under more favorable conditions, if it meets the conditions.

- on the other hand, the purchase of corporate bonds brings the investor a guaranteed, certain annual income.

- at the same time, the trade in debt securities significantly accelerates the development of the securities market, without which the securities market cannot be developed.

A bond is a debt security of a certain nominal value, by which its issuer undertakes to pay the investor, ie. the person by his order or bearer, the amount stated on it, with a certain interest on the due date of the bond for collection, ie. to pay the amount of annuity coupons (Fabozzi, Fabozzi, 1989). In the formal legal sense, the bond has three important features:

- nominal amount of debt, ie principal owed by the issuer,

- maturity date, the exact date when the borrowed amount is returned to the bondholder,

- nominal or coupon interest rate, as the yield of the bondholder (Šoškić, Živković, 2006). 
Bonds are, as a rule, long-term securities with a maturity of more than one year, with the purpose of identical issue of shares, ie. for the purpose of raising financial funds for the needs of the issuer. The bondholder is the issuer's creditor and has no management rights in the issuer, unless it owns bonds that can be converted into the issuer's share capital based on the will of the bondholder or bonds that are convertible into shares automatically (Giyon, 1984). The shares acquired through the conversion also give the owner personal management rights. The claim of the bondholder against the issuer is, as a rule, fixed and is related to the nominal value of the bond and the determined amount of interest. (Vasiljević, 1999). The holder of the bond secured by the guarantee does not bear any risk, and if it is a bond that is not secured the guarantee bears the risk of insolvency and bankruptcy of the bond issuer. The bondholder's claim is at the same time the issuer's debt, the bondholder's claim can be secured by a guarantee in which case it does not represent risk capital (Rodiere-Opetit, Hamel, 1984).

The motives of bond investors are generally twofold:

- Collection of income paid by the issuer and thus return on investment with earnings, in a larger amount than the one invested,

- Increasing the price of the bond on the market and thus gaining additional income through the secondary sale of securities on the market, at a price higher than the purchased one (Jovanović, 2006).

Investor motives often depend on the personality of the investor. Investors who are willing to invest only because of the stability of the price of securities and income (hedgers) buy mainly the so-called Secure securities. These are securities of safe and stable large issuers that have a successful and long business, come from stable markets and a good reputation, such as long-term government bonds or first-class large companies, which usually pay lower but secure interest rates compared to other issuers that pay more. Interest is higher and the investment risk is higher. In contrast, investors who want to acquire wealth quickly, with a willingness to take risks, often due to falling exchange rates, buy securities that "promise" rapid and significant growth in income, prices and capital gains (risk investors, speculators). Investments in such securities are significantly riskier than investments in safe bonds due to various internal and external influences, sudden changes in technology development or depletion of available natural resources (eg. oil companies) (Jovanović, 2006).

Bonds can be used as a means of payment in the circulation of goods and services, a means of securing payment, a means of securing loans, etc.

\section{Corporate bonds}

Corporate bonds are securities issued by companies, which oblige them to pay a defined coupon as well as the main debt on the due date of the bond within a predetermined period, on a precisely determined day. Corporate bonds are debt securities and also represent the means of financing the company's operations in order to raise additional funds for various reasons, such as financing current operations, mergers and acquisitions, or to expand business, refinansing debt (O'Sullivan, Sheffrin, Steven, 2003). Corporate bonds are issued through a public offering of bonds on the capital market and are purchased 
by various investors, institutional investors, including banks, insurance companies, pension funds, investment funds, international financial institutions and others.

The bond market plays a very important role in the economies of developed countries, as a mechanism of mutual relations of the issuer who is the user of capital and the buyer of bonds, investors. Corporate bonds are very important for large and mediumsized enterprises and can significantly contribute to improving their economic position.

\section{Protection of bondholders}

In many legal systems around the world, bond investors are provided with special protection measures, although they essentially have the status of a creditor, like all other lenders. The reason for this is the fact, that the corporate bond is burdened with credit risk (de risk), which at least theoretically does not burden the bonds issued by the state, because investing in government bonds is usually the safest, because the state cannot go bankrupt and is the issuer, at the same time the issuer of money. This is the essential difference between these two large groups of bonds. Compared to other instruments issued by corporations, the bond gives priority to the collection of receivables over the owners of ordinary and preferred shares.

The existence of credit risk and the level of its representation, causes modifications in the procedure of issuing corporate bonds in relation to government ones. The most significant modifications are the following:

- $\quad$ access to the bond issue market is more complex in regulatory terms,

- a high-risk issuer may, in order to provide security to bond investors, offer collateral in the event of default on its payment obligations. This can be the real assets of the issuer, which can be sold and used to cover liabilities, a guarantee of a third party (usually a bank) or securities owned by the issuer. This is a collateral of bonds, which, in that case, are allocated to a special group of collateral-secured bonds (collateral, trust, bonds). Certainly, their rating is of great importance for the security of investments in corporate bonds (Šoškić, Živković, 2006).

The rights of bondholders, of all or some types, are regulated in the legislation of countries due to the special sensitivity and complex activities of large investors, due to the need for enhanced protection of a large number of small and ignorant investors and special measures of supervisory authorities regulating the securities market, strict conditions and reduction of bond issue costs intended exclusively for professional investors (Jovanović, 2006). At the same time, in the course of the company's operations, there may be a need to change the established rights of bondholders (eg. reduction of interest rates, changes in the depreciation plan).

Although according to the rules of contract law, changing the established conditions that were valid at the time of issuing the bond, would not be in accordance with the law without the consent of the bondholder, a large number of experts believe that it would be necessary to have certain special rules that would allow bondholders to be organized in a similar way as shareholders, when it comes to expressing their will, and especially when it comes to protecting their collective, common rights. Serbian law, for now, there are no such regulations in this matter (Vasiljević, 1999). 
Unlike our country, in French law bondholders organize a specific "civil society", which are legal entities, governing bodies, an assembly that can make decisions by a prescribed majority of votes, which are determined by the nominal value of the bond and the decisions are binding on each individual holder of bonds. Bondholders who are at the same time shareholders with at least $10 \%$ of the issuer's capital are prohibited from participating in the General Meeting. The Assembly of bondholders gives its opinion to the Assembly of Shareholders of the issuer on the merger of the issuer, change of activity, change of legal form, issue of bonds that give greater rights than they have. In this case, the scope of the decision of the assembly of bondholders is limited, but not accepting such decisions of the issuer does not prevent their adoption, but in that case the issuer is obliged to pay the claims of bondholders who request it within a certain period. But the shareholders 'assembly cannot, without the consent of the bondholders' assembly, make decisions that change their bond rights. In any case, the decisions of the general meeting of bondholders and shareholders of the issuer cannot increase liabilities from already issued bonds, force the conversion of bonds into shares or determine different rights of bondholders of the same series (Loi sur les societas commerciales). But more recently, French theory has increasingly argued that such provisions are unnecessary, as bond buyers are increasingly institutional investors, who are professional in the securities business, economically more powerful than the issuer and in a position to create rules (Guyon , 1984).

American and English law use a trust deed for these cases, and a trustee is mainly a trust company, which is placed between the owner of the capital and the owner of the bond, with the obligation to act as a fiduciary. Since he must take care of the interests of the bonds, the trustee protects their interests with a special mortgage on the issuer's property and a floating pledge on the rest of the property, which gives great security to both professional investors and dispersed bondholders and the issuer's investor confidence and ability to raise capital. With this approach, it is possible to impose on the issuer the obligation to inform bondholders about important issues in the issuer's business. In these systems, there is a bondholders' assembly that decides by a prescribed majority of bondholders, whose decisions are binding on all bondholders and is authorized to convene a trustee when it deems it necessary, and in the event of certain important events, the trustee is obliged to convene an assembly, informing bondholders and making timely decisions (Boyle, Birds, Company Law, 1995).

Trading in these corporate bonds is performed on stock exchanges and on the overthe-counter market, which depends on the quality, ie. the rating of the bonds. As a rule, high quality bonds are traded on stock exchanges.

Corporate bonds are often issued as callable bonds, with a call option, which allows the issuer to redeem the bond at a fixed price before maturity. The issuer will take advantage of this if the company issues a bond with a high coupon rate in circumstances where there are high market interest rates, and then there is a fall in the general level of interest rates. In these circumstances, bonds with high coupon rates are withdrawn, and payment is made by a new issue with lower coupon rates. The presence of this clause is a source of a special type of risk that can be designated as a risk of revocation. The call clause reduces the market value of the bond. The call or bond revocation price is, as a rule, initially set at a level close to the par value and one-year coupon yield. The recall price decreases over time, gradually reaching a par value. In the case of revocable bonds, 
the initial period in which the bond cannot be revoked is usually defined. Such bonds are known as deffered callable bonds (Šoškić, Živković, 2006).

In contrast, the so-called. put table bonds, give this option to the bondholder. If the coupon rate of the bond exceeds the current market yield, it is logical to expect the owner to hold the bond in his portfolio. Otherwise, it is better to use the path option.

Companies can issue convertible bonds. It is a type of bond that gives the owner the opportunity to replace the bond with a predetermined number of shares of the issuer (Law on Companies of the Republic of Serbia). The conversion factor determines the number of shares for which the bonds can be exchanged, which gives the holder a significant advantage due to which these bonds have a lower coupon rate than standard corporate bonds. The promised yield to maturity of the bond is lower compared to nonconvertible bonds, but at the same time, the actual yield on the convertible bond may be higher than the promised yield to maturity, if converting into shares becomes profitable (Vasiljević, 2012).

Floating rate bonds and notes were created in early 1974. They arose due to the need to protect investors in the event of rising inflation. These bonds generate interest payments that are tied to a specific current market rate of return. The main risk of this type of bond is the variability of the issuer's creditworthiness. If the issuer's financial condition deteriorates, the market will demand a higher return than offered. In that case, the bond price will fall. This means that the coupon rate is adjusted for changes in the general level of market interest rates, but not for the financial performance of the issuer.

\section{Metodology and data sources}

Information and data used for reserch in this paper, which refer to the possibilities of issuing corporate bonds as a way of financing the business of companies ......... were obtained during a detailed interview with members of the executive board of directors of a rating company from Belgrade, very experienced in providing consulting services for the assessment of the quality of securities in Serbia, researching the securities market for the assessment of business results, predictability of future cash flows and the amount of indebtedness of companies and the issuance of securities. Additional data related to foreign securities markets are the result of many years of research by authors, relevant foreign scientific and professional literature, foreign institutions that play a role in capital market operations, analysis of practical examples and publicly available information via the Internet.

The main goal of this paper is to show the potential of economic effect that arises from financing companies by issuing debt securities. The research was conducted on the Serbian market for the last two years, including the issuance of corporate bonds by a medium-sized company from Belgrade.

The economic justification for the issue of corporate bonds was determined on the basis of lower costs of selling debt securities, obtaining higher amounts of funds from a large number of buyers and in the short term.

The success of the bond issue can undoubtedly be assumed based on the reputation that the issuer has in the environment where it operates and beyond, which means the length of the issuer's business, business in the previous period, introduced good corporate governance and socially responsible business of the issuer. 


\section{Results with discussion}

\section{High grade and high yield of corporate bonds}

According to credit rating, corporate bonds are divided into two main categories high grade (also called investment grade) and high yield (also called non-investment grade, speculative grade, or junk bonds). Bonds rated AAA, AA, A, and BBB are high grade, while bonds rated BB and below are high yield (Rose, Marquis, 2006). High grade and high yield bonds are traded by different trading markets and held by different investors. Given that corporate bonds have a higher credit risk than government bonds, it is logical to expect that investing in corporate bonds will generate higher earnings, but there is also a very differentiated structure among issuing companies regarding investment risk and return, which refers to the following:

- one type of risk is credit risk that may arise if the issuer fails to meet its obligations. If the credit risk is higher, the bond interest rate is higher and the price is lower. With government bonds, this risk does not exist,

- $\quad$ interest rate risk is the possibility of changing the interest rate on the market that determines the price of bonds in secondary turnover. The change in interest rates inversely affects the change in the price of bonds on the market,

- liquidity risk is the probability that may not be a continuous secondary market for a bond, thus leaving an investor with difficulty in selling at, or even near to, a fair price. This particular risk could become more severe in developing markets (Vuong, Tran, 2010).

- $\quad$ supply risk, more heavy issuance of new bonds similar to the one already issued may reduce their prices.

- inflation risk is the probability that there will be inflation that was not taken into account when forming the nominal interest rate of the bond. Inflation reduces the real value of future fixed cash flows and can reduce prices immediately.

- tax change risk, unanticipated changes in taxation may adversely impact the value of a bond to investors and consequently its market value.

- There is also a risk of changes in foreign exchange rates that arise when the issuer undertakes to make payments in one currency and the buyer of a corporate bond cannot know with certainty what the cash flow will be expressed in another currency.

\section{Characteristics of the corporate bond market in Serbia}

The capital market in the Republic of Serbia has a high degree of development in the field of government debt securities, government bonds. Government bonds are traded on the Belgrade Stock Exchange using the continuous method and are listed on the A Listing, as the highest quality securities on the stock exchange. The Republic of Serbia successfully issues bonds denominated in dinars and euros with a maturity of up to 20 years, whose buyers are domestic and foreign institutional investors. In contrast, the corporate bond market is under development and the issuers of bonds listed on the regulated market of the Belgrade Stock Exchange are some commercial banks (eg Erste Bank bonds, worth RSD 3.5 billion, issued with a maturity of 3 years) and several private 
companies. As of 2020, there are a very small number of corporate bond issuers on the domestic market, a total of eight bond issuers, of which one is a bank and several companies (http://www.crhov.rs/?Opcija $=5 \&$ TipHartije=kratkorocne).

During the state of emergency caused by COVID-19 in 2020, the Government of Serbia, as part of a package of measures to mitigate the economic effects of the pandemic, adopted a Decree on the procedure for issuing debt securities, with the aim of encouraging the use of an additional source of capital to provide funds for business and investment projects in the coming period, by issuing bonds. The adopted rules simplify the procedure of issuing bonds during the state of emergency and in a certain period after that and, at the same time, clearly show the interest of relevant state stakeholders to encourage the way of financing companies with bonds, but that did not contribute to the issuance of new bonds and thus to the financing of the company's operations in that way in Serbia.

The bond market in Serbia has special specifics:

- low liquidity, weak demand and high risks, instability of the entire securities market and simplified structure of financial instruments,

- high concentration of ownership in the hands of individual new capitalists, geographically dominated by the capital and regional centers,

- less transparency and effectiveness of the market, a higher degree of insider information, various forms of market fairness violations and thus weaker protection of investors' rights,

- a large role of foreign investors, without adequate reciprocity and a very weak role of the population as an investor,

- the role of the state is reduced to the creation of laws and rules, supervision over compliance with the law and transparency of information (Janković, 2006,).

- a significant contribution to strengthening liquidity and developing the corporate bond market in Serbia would be the possible participation of the National Bank of Serbia in the purchase of bonds on the secondary market (with a maximum maturity of up to 5 years and a minimum credit rating of B).

\section{Financing companies by issuing bonds}

By issuing corporate bonds directly to investors, the role of a commercial bank is actually omitted, which is why financing is often cheaper. In addition, a bond is a more useful instrument than a bank loan because a company is spared negotiating with more creditors if it borrows larger amounts - a bond is the only instrument that can borrow large amounts of capital from a large number of investors without special negotiations between the company and investors.

Also, unlike a classic loan, a debt financial instrument can be bought or sold on the secondary market. In fact, a bond is a loan that is intended to be traded on the market and earn.

The advantage of bonds in relation to bank loans is that annual installments are not paid, but interest together with the main debt is paid at the end of the repayment period, which frees up the cash flow of companies.

When issuing bonds, the issuer determines the conditions related to debt structuring and the amount of interest, which in the case of a bank loan is determined by the 
commercial bank in accordance with its internal rules and law. If he wants to raise money by issuing bonds, the issuer must take care to set realistic conditions related to debt and interest structuring, so that the investor was interested in buying bonds, because from the sale of bonds, both parties, the issuer and the buyer expect to benefit ( Wood, 1995). The maturity of the main debt and the interest rate of a corporate bond are determined based on the creditworthiness of the issuer (business results, predictability of future cash flows and indebtedness), as well as by comparing the yields of comparable bonds and / or as a margin in relation to the known yield of government bonds sold on the market.

Differences in the realization of bank loans and corporate bonds: (https://home. kpmg/rs/en/home/insights/2020/04/korporativne-obveznice-novi-izvor-finansiranja-)

\begin{tabular}{|l|l|}
\hline \multicolumn{1}{|c|}{$\begin{array}{c}\text { B a n k } \\
\text { lo a n s }\end{array}$} & \multicolumn{1}{c|}{$\begin{array}{c}\text { Co r p o r a t e } \\
\text { b o n d s }\end{array}$} \\
\hline $\begin{array}{l}\text { Financial resources are provided by one or } \\
\text { more banks }\end{array}$ & $\begin{array}{l}\text { The funds are provided by the company by } \\
\text { issuing bonds }\end{array}$ \\
\hline $\begin{array}{l}\text { Financing terms are agreed between the } \\
\text { contracting parties in accordance with the rules } \\
\text { of the bank }\end{array}$ & $\begin{array}{l}\text { The issue is realized by issuing bonds through } \\
\text { a public offer for subscription and purchase of } \\
\text { bonds }\end{array}$ \\
\hline $\begin{array}{l}\text { There is no developed system of credit trading } \\
\text { on the secondary market }\end{array}$ & $\begin{array}{l}\text { The corporate bond is traded on the secondary } \\
\text { market }\end{array}$ \\
\hline There is a depreciation plan for the sale & $\begin{array}{l}\text { Payment from the bond is typically a lump } \\
\text { sum on the maturity date }\end{array}$ \\
\hline
\end{tabular}

\section{Bond rating}

Since investors buy bonds to make money, their goal is to invest in securities of those issuers who will pay interest and main debt at the time the corporate bond matures and assuming the existence / non-existence or elimination of other risks. The investor often does not have enough professional knowledge and experience to assess the quality of the issuer's bonds and thus how much he can earn, which is professionally done by rating agencies, which are in fact legal entities authorized to give an opinion on the issuer's future ability to fully and timely perform its obligations under the bond, based on a predefined and practice-based ranking system (Law on the Securities Market and other financial instruments). When assessing the rating of the issuer, agencies are mostly based more on the analysis of the financial position of the issuer than on how attractive the issue is on the market. The existence of the issuer's rating accelerates the issue of bonds and its sale on the market, which is why issuers are willing to pay for the services of rating agencies, which can provide them with an active market for their bonds (Bodie, Kane, Marcus, 2004).

But rating agencies do not rate all types of bonds. Government bonds (tresuries) are not subject to quality assessment because they are considered to be of the highest quality securities as the government has many instruments with which it can possibly raise funds to settle its obligations (Vasiljević, 1997). Corporation bonds are most often, subject to analysis by rating agencies, because they carry the risk of default from the bond and possible bankruptcy. The analysis of the financial situation includes the calculation of the company's financial ratios (liquidity ratios, financial leverage, profitability ratios, etc.), but also the collection of data that could affect its economic position, as well as the terms of bond issues that may affect bond quality. 
If the issuer provides collateral to ensure the payment of the obligation from the bond, or forms a repayment fund (sinking fund) from which the debt will be settled in case the company cannot fulfill that obligation, the rating agency determines the higher quality of the security. High-rated bonds are safer investments, but they carry low interest rates (risk and trade conditionality).

As mentioned above, the highest quality bonds are marked with the mark AAA, the lower rating is marked with a smaller number of letters A, and even lower with the following letters of the alphabet. In the process of collecting data for the assessment of the quality of emissions, there is usually a delay because new changes occur, so that investors cannot fully rely on the assessments of rating agencies.

Therefore, whether the issuer's shares will be attractive for purchase by investors, depends on the issuer's available capabilities, which are conditioned by the financial position and financial reputation of a given company in the area.

Financial position is assessed by (Subić, 2010):

- maintaining an adequate structure of financial resources and sources of financing of the issuer;

- acceptable capital structure from the point of view of equity and debt capital;

- ability to finance simple and extended reproduction works from the issuer's own funds.

Since the business of companies in Serbia is mainly based on private companies, open and competitive market, investments of bond buyers should be realized in a way that will ensure maximum efficiency of exploitation, ie. the highest possible level of effects per unit of invested funds (Rajnovic, Subić, Zakić, 2016).

The level of economic efficiency depends on the quantity and quality, the resources used, but also the results achieved. Economic efficiency represents the ratio of the obtained effects and the made investments or as the ratio of the made investments and the obtained effects (Rajnovic, Subić, Zakić, 2016).

The formulas for determining economic effectiveness are as follows (Românu, Vasilescu, 1993):

$$
e=\frac{E}{\varepsilon} \rightarrow \underset{\text { maximum or }}{e^{\prime}=\frac{\varepsilon}{E} \rightarrow \text { minimum }}
$$

where are they:

$e$ and $e^{\prime}-$ economic efficiency;

$E$ - obtained effects;

e - investments made.

Based on the first mathematical expression, the economic effect is determined, which is realized per unit of measure of investments made and which should be the maximum (Rajnovic, Subić, Zakić, 2016).

Based on the second mathematical expression, investments are determined that are realized per unit of measure of the obtained economic effects and which are satisfactory if they are minimal (Rajnovic, Subić, Zakić, 2016).

Making investment decisions, regardless of the business conditions, should be based on strict quantitative and qualitative criteria, which will ensure investment in the 
most efficient businesses. Therefore, when deciding to buy corporate bonds, the investor must use adequate methods, techniques and models to assess the economic effectiveness of investments to ensure that its funds are invested in the right way and to achieve the best possible results(Rajnovic, Subić, Zakić, 2016) .

\section{Conclusion}

Financing of companies by issuing corporate bonds is undoubtedly of great importance not only for the issuer and the investor, but also for the development of the entire securities market. Therefore, but also because of the specifics of bonds, it is necessary to adequately organize and regulate the corporate bond market, which regulates who can be a participant in the bond market, under what conditions can participate in this contractual relationship - issuance and purchase of bonds, what are the costs of trade, whose interests should be protected and why.

Bond market regulation and legal certainty depend on a number of fundamental economic and legal factors, influencing market ideology, market development and coordination, legal rules and practices, which provide legal certainty for corporate bond market participants, market regulation, control and supervision of procedures. participants, transparency and equal access to information on the issuer's risks and the prices of securities, which may be the subject of trading.

In Serbia, an active state strategy is needed, primarily to encourage and then further develop the corporate bond market, with appropriate improvement of the legal framework, laws governing companies, corporate bond markets, risk reduction and a system of economic incentives for investors and other market participants. The ultimate goals are to attract investment in the real sector of the economy and to raise the level of legal certainty in the bond market.

It is clear that the issuance and trade of corporate bonds in Serbia has been neglected and that companies are currently not represented as issuers nor do they see advantages for financing through bond issues. It is difficult for them to find a guarantor of the emission, given the general uncertain economic situation. Also, due to such a risk, financing through bonds turns out to be more expensive than taking loans from commercial banks. Numerous joint stock companies also obtain long-term financing through recapitalizations, mainly from closed issues.

\section{Literature}

Bodie, Z. Kane, A., Marcus, A.J. (2004) Droit des marches de capitaux, LGDJ

Boyle, A.J. \& Birds, J. Company Law, 1995. London, p. 263-265

Frank J. Fabozzi \& Dessa Fabozzi, Bond Markets, Analisys and Strategis, Prentice Hall International Inc. 1989, p. 1

Giyon, Y. Droit des Affaires, Economica, Paris, 1984. str. 730

Janković, Miloš, (2006) Securities Market and Legal Security, Law and Economy no. 5-8, Associations of Lawyers in the Economy of Serbia, p. 872-880. 
Jovanović N. 2006, Emission (issue) of serial securities, Joint stock companies, stock exchanges and shares, Faculty of Law, University of Belgrade, p. 661-688

Piljan, I., Simonović, Z., \& Ćurčić, N. (2020). The influence of teamwork as an internal marketing factor on the quality of the service of insurance companies in Serbia's agricultural sector. Ekonomika poljoprivrede, 67(1), 189-206.

Rajnović, Lj., Subić J., Zakić N., (2016) Organizational and financial restructuring of companies in the function of improving the economic environment in the Republic of Serbia, Institute of Agricultural Economics, Belgrade RodiereOpetit, Droit commercial, Paris 1984, str. 284-286; Hamel - Lagarde-Jauffret, Droit commercial, Paris, str. str. 268-271

Românu, I., Vasilescu, I. - Eficienţa economică a investiţiilor şi a capitalului fix, Ed. Didactică şi Pedagogică, Bucureşti, 1993.

Rose, P.S., Marquis, M.H., (2006), Money and capital markets, Boston, McGraw-Hill

Subić J. (2010): Specifics of the process of investing in agriculture. Institute of Agricultural Economics, Belgrade.

O’Sullivan, Arthur; Sheffrin, Steven M. (2003). Economics: Principles in Action. Upper Saddle River, New Jersey 07458: Pearson Prentice Hall. p. 281. ISBN 0-13-063085-3.CS1

Vasiljević, B.A., (1997), Fundamentals of financial market, Belgrade, Diamond Hard

Vasiljević M. 1999, Companies, Association of Lawyers in the Economy of FR Yugoslavia, Belgrade, p. 253

Vasiljević, M. (2012) Guide for the implementation of the new law on companies, Association of Lawyers in the Economy of Serbia, Belgrade, Serbia, p. 368

Vuong, Quan Hoang; Tran, Tri Dung (2010). "Vietnam's Corporate Bond Market, 1990-2010: Some Reflections" (PDF). The Journal of Economic Policy and Research. Institute of Public Enterprises. 6 (1): 1-47.

Šoškić, D., Živković, B., 2006, Financial markets and institutions, Faculty of Economics, Belgrade, Serbia

Wood, P. (1995) International loans: Bonds and securities regulatin, London, Swetr\&Maxwell

Franch law, Loi sur les societas commerciales, article 284-339

Law on Companies (“Official Gazette of RS", No. 36/2011 and 99/2011, 83/2014 other Law, 5/2015, 44/2018 and 95/2018)

Law on Market of Securities and Other Financial Instruments ("Official Gazette of RS", No.31/2001, 112/2015, 108/2016 and 9/2020)

Decree on the Procedure for Issuing Debt Securities (Official Gazette of RS, No.54/2020)

https://www.danas.rs/ekonomija/korporativne-obveznice-su-za-dobra-vremena-ne-za-krizu/

https://home.kpmg/rs/en/home/insights/2020/04/korporativne-obveznice-novi-izvorfinansiranja-

http://www.crhov.rs/?Opcija=5\&TipHartije=kratkorocne 